\title{
Prevalence of sun exposure and its associated factors in southern Brazil: a population-based study ${ }^{*}$
}

Prevalência e fatores associados à exposição solar no sul do Brasil: um estudo de base populacional

\author{
Rodrigo Pereira Duquia ${ }^{1}$ \\ Felipe Fossati Reichert ${ }^{4}$ \\ Bernardo Lessa Horta ${ }^{6}$
}

\author{
Ana Maria Baptista Menezes ${ }^{2}$ \\ Iná da Silva dos Santos ${ }^{5}$
}

\author{
Hiram Larangeira de Almeida $\mathrm{Jr}^{3}$ \\ Ricardo Lanzetta Haack ${ }^{6}$
}

DOI: http://dx.doi.org/10.1590/abd1806-4841.20132122

\begin{abstract}
BACKGROUND: Sunlight exposure is responsible for a large number of dermatological diseases. OвJестіVE: We estimated the prevalence of sunlight exposure and its associated factors in adults from southern Brazil in a cross-sectional, population-based study. METHODs: We investigated a representative sample of individuals aged $\geq 20$ years $(n=3,136)$. Sunlight exposure and its associated factors were evaluated in two distinct situations: at leisure time and at work. The time period investigated ranged from December 2004 to March 2005, comprising 120 days of the highest ultraviolet index in the urban area of the city of Pelotas, in southern Brazil. The participants were asked about sunlight exposure for at least 20 minutes between 10 A.M. and 4 P.M. The analysis was stratified by sex, and sunlight exposure was grouped into five categories. RESULTs: Among the 3,136 participants, prevalence of sunlight exposure at the beach was $32.8 \%(95 \% \mathrm{CI}, 30.3-35.2)$ and $26.3 \%$ (95\% CI, 24.2 28.3) among men and women, respectively. The prevalence at work was 39.8\% (95\% CI, $37.2-42.4$ ) among men and $10.5 \%$ (95\% CI, $9.1-12.0)$ among women. Age was inversely associated with sunlight exposure. Family income and achieved schooling were positively associated with sunlight exposure at leisure time and inversely associated with sunglight exposure at work. Self-reported skin color was not associated. Knowledge of any friend or relative who has been affected by skin cancer was positively associated with sunlight exposure among men at work. CONCLUSION: Despite the media campaigns on the harmful effects of excessive sunlight exposure, we found a high prevalence of sunlight exposure during a period of high ultraviolet index.

Keywords: Environment and public health; Precancerous conditions; Public health practice; Skin neoplasms; Sunbathing
\end{abstract}

Resumo: Fundamentos: A exposição solar é responsável por um grande número de doenças. OBjetivos: Nós estimamos a prevalência e fatores associados à exposição solar em adultos do sul do Brasil em um estudo transversal de base populacional. MÉTodos: Uma amostra representativa de indivíduos com idade $\geq 20$ anos (n=3,136). A exposição solar foi avaliada no lazer e durante o trabalho. O período de investigação foi de dezembro de 2004 a março de 2005, compreendendo os 120 dias de maior intensidade solar. Os participantes foram questionados sobre exposição solar por pelo menos 20 minutos entre as 10 as 16 hs. A análise foi estraificada por sexo e a exposição solar foi agrupada em 5 categorias. RESULTADOS: Entre os 3,136 participantes, a prevalência de exposição solar na praia foi de 32.8\% (IC95\% 30.3 - 35.2) e 26.3\% (IC95\% 24.2 - 28.3) entre homens e mulheres, respectivamente. A prevalência de exposição no trabalho foi de 39.8\% (IC95\% 37.2 - 42.4) entre homens e 10.5\% (IC95\% 9.1 - 12.0) entre mulheres. A idade esteve inversamente associada à exposição solar. Renda familiar e escolaridade estiveram positivamente associadas à exposição solar durante o lazer e inversamente associada durante o trabalho. A cor de pele auto referida não esteve associada. O conhecimento de qualquer amigo ou parente que tenha sido acometido por um câncer de pele esteve positivamente associado à exposição solar apenas entre os homens durante o trabalho. CONCLUSÕEs: Apesar das campanhas advertindo sobre os perigos do sol, nós encontramos uma alta prevalência desse desfecho nos períodos de maior intensidade solar.

Palavras-chave: Banho de sol; Lesões pré-cancerosas; Meio ambiente e saúde pública; Neoplasias cutâneas; Prática de saúde pública

\footnotetext{
Received on 11.09.2012.

Approved by the Advisory Board and accepted for publication on 04.10.2012.

* Work performed at Federal University of Pelotas - Pelotas (RS), Brazil.

Conflict of interest: None

Financial funding: None

Professor, Federal University of Health Sciences of Porto Alegre - Porto Alegre (RS), Brazil.

Department of Social Medicine, Federal University of Pelotas - Pelotas (RS), Brazil.

Faculty of Medicine, Federal and Catholic University of Pelotas - Pelotas (RS), Brazil

Professor, Department of Gymnastics and Health, Federal University of Pelotas - Pelotas (RS), Brazil.

Postgraduate Program in Epidemiology, Federal University of Pelotas - Pelotas (RS), Brazil.

Postgraduate Program in Epidemiology, Federal University of Pelotas - Pelotas (RS), Brazil. 


\section{INTRODUCTION}

Sunlight exposure is responsible for a large number of dermatological diseases. ${ }^{1}$ In recent decades, there has been an increasing occurrence of cutaneous neoplasms, which is consistent with the changing pattern of exposure to the sun described in many populations. ${ }^{2-4}$ Currently, a large body of evidence demonstrates that efforts to delay skin aging and to decrease skin cancer incidence around the world primarily depend on the reduction of sunlight exposure. ${ }^{4,5}$

Until the end of the $19^{\text {th }}$ century, the elite's aesthetic ideal was characterized by lighter skin, since it was a marker of higher social status. After the Industrial Revolution, individuals from lower social strata were more likely to perform their labor activities indoors and, consequently, lighter skin was no longer regarded as an important indicator of higher social status. ${ }^{3}$ The discovery, at the same time period, of the beneficial effect of ultraviolet radiation on the synthesis of vitamin $\mathrm{D}$ in the skin was followed by a period of enormous popularity of sunlight exposure. ${ }^{6,7}$ Gradually, tanned skin became recognized as a synonym of good health and affluence, since it was a privilege of only those who had enough free time to practice outdoor activities and to attend summer vacation sites.

In Brazil, such a change in the patterns of sunlight exposure occurred in the early 1920's, when sport activities gained popularity. From this time on, sunlight exposure became socially desirable, and cycling as well as bathing in the sea became frequent. After the 1930's, tanned skin turned into the new aesthetic ideal in Brazil, and there was an increase in the frequency of time spent on bathing in the sea and swimming pools. During that decade, the first tanning oils were developed, and it became fashionable for individuals to expose larger areas of their bodies, such as legs, arms, chest, and the back. ${ }^{8,9}$

Dermatologists and other physicians today are confronting the effects of changes in the social behavior related to sunlight exposure that took place in the last century. This change in social behavior hinders the effective control of the increasing worldwide incidence of skin cancer.

The present study aimed at estimating the prevalence of sunlight exposure and its associated factors between December 2004 and March 2005, the period of highest ultraviolet index in southern Brazil, in two distinct situations: at leisure time (including at the beach) and at work.

\section{METHODS}

Between October and December 2005, a crosssectional, population-based study was carried out in Pelotas, a 320,000-inhabitant city in the far South of
Brazil. Pelotas is located at 31 degrees South latitude and is characterized by subtropical weather and four definite seasons. All individuals aged ${ }^{3}$ more than 20 years living in the urban area of the city $(93.2 \%$ of the whole population) comprised the target population of this study. ${ }^{10}$

In order to estimate a prevalence of sunlight exposure at leisure time and at work of $20 \%$ with a sample error of \pm 3 percentage points, at least 682 individuals would have to be interviewed. Both sample size calculations used the following parameters: $95 \%$ confidence interval, $80 \%$ power, and an additional $10 \%$ to cover refusals and $15 \%$ for multivariable analyses.

Because this study was part of a larger investigation on the general health of the population, which included other outcomes requiring larger sample sizes, the eligible sample comprised 3,353 individuals.

The sampling process was undertaken in two main stages. Initially, all 404 census tracts from Pelotas, as defined by the Brazilian Institute of Geography and Statistics, were listed according to the average income level of the family's breadwinner. Then, 120 census tracts were sampled with probability proportional to size. Within the census tracts, approximately 13 households were systematically selected so that all households in each of them had the same probability to be included in the study. This resulted in 1,597 households to be visited and 3,353 eligible adults to take part in the study. ${ }^{10}$

Interviewers collected information regarding sunlight exposure during the last summer (from December 2004 to March 2005) at leisure time (including at the beach) and at work from all adults in each of the visited households. Those who reported to be exposed to sunlight for at least one day at leisure time or at work without the aid of sun-protection devices during the observed period (120 days) were asked to report how many days they were exposed to sunlight for at least 20 minutes between 10 A.M. and 4 P.M. from December 2004 to March 2005 (the outcome of interest).

For analytical purposes, the outcome was divided into five ordered categories of sunlight exposure: (a) no exposure at all; (b) 1-7 days; (c) 8-14 days; (d) 1530 days; and (e) $>30$ days of sunlight exposure out of the 120 days.

Information on the following independent variables was collected: age (20-29, 30-39, 40-49, 50-59 and $\geq 60$ years old), self-reported skin color (black, brown and white), achieved schooling (0-4, 5-8, 9-11 and $\geq 12$ years of successfully completed formal education), monthly family income (in quartiles), and knowledge of any relative or friend who has been affected by skin cancer (yes/no). 
Female interviewers blinded to the study hypothesis performed all data collection using standardized and pre-coded questionnaires. Sunlight exposure was investigated in two different situations: at leisure time (including sunbathing at the beach, at a swimming pool or anywhere else), and at work.

The questionnaire was tested twice in pilot studies carried out in census tracts not included in the final sample. Fieldwork supervisors repeated the interviews in $10 \%$ of the sample, selected at random, asking questions contained in a shortened version of the questionnaire in order to test the reproducibility of some questions and to assess quality of data collection. The Kappa value for achieved schooling was 0.72 .

Data were entered twice in Epi Info 6.04 for automatic checks of consistency and range. Stata version 9.0 was used in the data analysis. Since the dependent variable was divided into five ordered categories, ordinal logistic regression was used in multivariable analysis. Backward elimination procedure was adopted, and all variables with a $p$-value $<0.20$ remained in the model to control for confounding. Ordinal logistic regression produces estimates that can be interpreted as the odds ratio of being in a higher category of the outcome for a one-unit change in the independent variable. The assumption of parallel regression was assessed using Brant's test. Since differences between men and women with regard to sunlight exposure and associated factors are found in the literature, the analyses were stratified by sex.
The Ethics Committee of the Federal University of Pelotas approved the study protocol, and written consent was obtained from every participant.

\section{RESULTS}

From a total of 3,353 eligible adults, $93.5 \%$ were interviewed (Figure 1). Among the 3,136 adults interviewed, prevalence of sunlight exposure at the beach for at least 20 minutes on at least one day between 10 A.M. and 4 P.M in the observed period was $32.8 \%$ (95\% CI, 30.3-35.2) and 26.3\% (95\% CI, 24.2-28.3) among men and women, respectively. The prevalence of sunlight exposure at work was 39.8\% (95\% CI, 37.242.4) among men and 10.5\% (95\% CI, 9.1-12.0) among women (Figure 1). Considering only those exposed to sunlight for at least one day in the studied period, the median number of days of sunlight exposure at leisure time was 10 among men and 7 among women. At work, this value was 80 for men and 50 for women. Sunlight exposure intra-class correlation coefficient at the beach and at work was 0.05 . The corresponding design effects at leisure time and at work were 2.2 and 2.4 , respectively.

Table 1 displays the sample distribution and the prevalence of sunlight exposure (1 day of sunlight exposure between 10 A.M. and 4 P.M. from December 2004 to March 2005) according to the independent variables. The average age was 44.1 years $(\mathrm{SD}=16.4)$. The higher the age, the lower the prevalence of sunlight exposure at leisure time and at work. Whites and

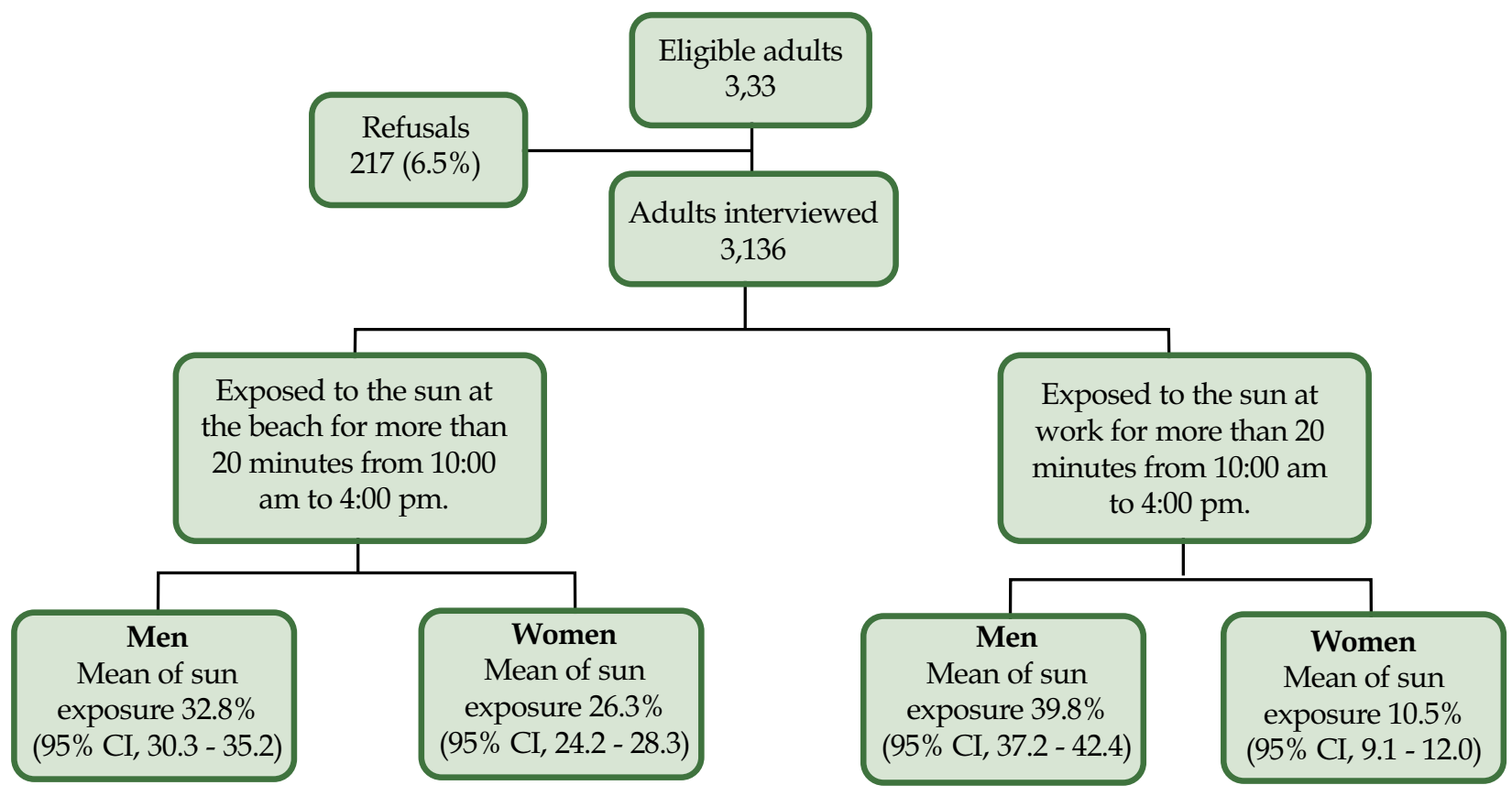

FIGURE 1: Sample distribution according to each studied situation 
TABLE 1: Sample distribution according to the independent variables and prevalence of sunlight exposure at leisure time (beach) and at work. Adults from Pelotas, Brazil

\begin{tabular}{|c|c|c|c|c|c|c|c|}
\hline \multirow[t]{3}{*}{ Variables } & \multirow{3}{*}{$\begin{array}{l}\text { Whole } \\
\text { sample }\end{array}$} & \multicolumn{3}{|c|}{ LEISURE TIME } & \multicolumn{3}{|c|}{ WORK } \\
\hline & & \multicolumn{2}{|c|}{ Exposed $^{\ddagger}$} & \multirow[t]{2}{*}{$P$ value } & \multicolumn{2}{|c|}{ Exposed $^{\ddagger}$} & \multirow[t]{2}{*}{ P value } \\
\hline & & $\overline{\mathbf{N}}$ & $(\%)$ & & $\mathbf{N}$ & $(\%)$ & \\
\hline Age (years) & & & & $<0.001^{*}$ & & & $<0.001^{*}$ \\
\hline $20-29$ & 747 & 361 & 48.5 & & 175 & 23.4 & \\
\hline $30-39$ & 611 & 196 & 32.1 & & 186 & 30.4 & \\
\hline $40-49$ & 661 & 179 & 27.1 & & 199 & 30.1 & \\
\hline $50-59$ & 520 & 100 & 19.2 & & 110 & 21.2 & \\
\hline$\geq 60$ & 597 & 75 & 12.6 & & 62 & 10.4 & \\
\hline Sex & & & & $<0.001^{\dagger}$ & & & $<0.001^{\dagger}$ \\
\hline Male & 1378 & 450 & 32.8 & & 547 & 39.8 & \\
\hline Female & 1758 & 461 & 26.3 & & 185 & 10.3 & \\
\hline Self-reported skin color & & & & $0.07^{*}$ & & & $0.02 *$ \\
\hline Black & 338 & 82 & 24.3 & & 97 & 28.7 & \\
\hline Brown (pardo) & 227 & 63 & 27.8 & & 57 & 25.1 & \\
\hline White & 2571 & 766 & 29.8 & & 578 & 22.5 & \\
\hline Achieved schooling (years) & & & & $<0.001^{*}$ & & & $<0.001^{*}$ \\
\hline $0-4$ & 783 & 99 & 12.6 & & 208 & 26.6 & \\
\hline $5-8$ & 1005 & 250 & 24.9 & & 295 & 29.4 & \\
\hline $9-11$ & 824 & 306 & 37.1 & & 161 & 19.5 & \\
\hline$\geq 12$ & 522 & 256 & 49.0 & & 68 & 13.0 & \\
\hline \multicolumn{8}{|l|}{ Per capita monthly family } \\
\hline income in quartiles (U\$) & & & & $<0.001^{*}$ & & & $<0.001^{*}$ \\
\hline $1^{\text {st }}(0$ to 70$)$ & 780 & 165 & 21.2 & & 244 & 31.3 & \\
\hline $2^{\text {nd }}(70.1$ to 133$)$ & 804 & 205 & 25.5 & & 223 & 27.7 & \\
\hline $3^{\text {rd }}(133.1$ to 267$)$ & 786 & 247 & 31.4 & & 157 & 20.0 & \\
\hline $4^{\text {th }}(267.1$ to 8889$)$ & 745 & 286 & 38.4 & & 101 & 13.6 & \\
\hline \multicolumn{8}{|l|}{ Knowledge of any friend } \\
\hline or relative with skin cancer & & & & $0.06^{\dagger}$ & & & $0.06^{\dagger}$ \\
\hline No & 2602 & 737 & 28.3 & & 626 & 24.1 & \\
\hline Yes & 534 & 174 & 32.6 & & 106 & 19.9 & \\
\hline Total & 3136 & 911 & 29.0 & & 732 & 23.3 & \\
\hline
\end{tabular}

* Wald test for linear trend.

† Wald global association test.

¥ The denominator for exposed individuals included the whole sample 
browns were less likely to be exposed to sunlight at work. At leisure time, whites and browns were more likely to be exposed to sunlight; however, due to the limited number of individuals in the remaining skin color category, this result was not statistically significant. In respect to achieved schooling and per capita monthly family income, the pattern of sunlight exposure depended on whether it was at leisure time or at work. At leisure time, achieved schooling and per capita family income were positively associated with sunlight exposure. At work, this association was the opposite. Knowledge of any relative or friend who has been affected by skin cancer was not associated with sunlight exposure (Table 1).

Table 2 shows the crude and adjusted odds ratio of sunlight exposure among men according to the independent variables. It is clear from this table that sunlight exposure was statistically and inversely associated with age in both situations, at leisure time and at work. On the other hand, self-reported skin color was not associated in the adjusted analysis.

At leisure time, men with higher achieved schooling and higher per capita monthly family income were more likely to be exposed to sunlight. At work, higher achieved schooling and income were inversely associated with sunlight exposure. After adjustment for confounding factors, the variable "knowledge of any relative or friend who has been affected by skin cancer" was associated with sunlight exposure at work. Men reporting knowledge of any relative or friend affected by skin cancer were 1.52 (95\% CI, 1.08-2.13) times more likely to be in a higher category of sunlight exposure at work than those who had no friends or relatives with skin cancer.

Table 3 displays the crude and adjusted odds ratio of sunlight exposure among women according to the independent variables. Age was also inversely associated with sunlight exposure in women, whereas self-reported skin color was not.

Among women, achieved schooling and per capita monthly family income showed patterns of association with sunlight exposure similar to the ones observed among men in both situations. At leisure time, the adjusted odds ratio for women with ${ }^{3} 12$ years of achieved schooling or a per capita monthly family income ${ }^{3}$ of U\$267.10 were 4.93 (95\% CI, 3.107.87) and 2.02 (95\% CI, 1.27-3.21), respectively. At work, women with higher family income were protected from being in a higher category of sunlight exposure (odds ratio: 0.52; 95\% CI, 0.30-0.90). There was no association between sunlight exposure and knowledge of any relative or friend who has been affected by skin cancer among women.

\section{DISCUSSION}

Sunburn and excessive sunlight exposure are positively related to the development of some neoplasms, such as those of the eye and skin. ${ }^{11,12}$ Furthermore, sunlight exposure plays an important role in the development of sunburns, accelerates cutaneous aging, and is also associated with the appearance of cataracts, pterygium and solar keratoses. ${ }^{1,13,14}$ The acute response of human skin to excessive solar radiation is characterized by sunburns and local immunosupression, while the development of skin cancers, cutaneous aging and some eye tumors are the result of chronic solar radiation exposure. ${ }^{1,13,14}$ Skin cancer typically occurs in the photo-aged skin, and its incidence is recently increasing in many countries.,15

Since the 1980's, many mass media campaigns have drawn attention to the dangers of sun exposure and the benefits of sun protection. ${ }^{16}$ Moreover, health authorities have stimulated preventive measures to reduce sun exposure among population groups all over the world. In a study carried out between 1986 and 1996 to measure changes in behaviors that affect skin cancer risk, the authors noted that knowledge of the perceived harmful effects of the sun significantly broadened, but, simultaneously, the ultraviolet exposure behavior as measured by sun burning and regular use of a tanning booth also increased. ${ }^{16}$

With regard to achieved schooling and per capita monthly family income, the effect of these variables depended on the situation considered, as seen in tables 2 and 3. For example, men and women with higher achieved schooling and higher monthly family income were more likely to be exposed to sunlight at leisure time. This finding may be the result of an unconscious aspiration to some aesthetic ideal in our society, since individuals with tanned skin are regarded as healthier. In a study conducted by Robinson et al in the United States, higher-income individuals considered tanned skin healthy and, consequently, were more likely to expose themselves to sunlight than lower-income individuals. ${ }^{16}$

With respect to sunlight exposure at work, the effect of higher achieved schooling and per capita monthly family income were the opposite of that observed at leisure time. This result is possible due to the fact that individuals with higher social status tend to perform their labor activities indoors.

In a study conducted in the United States with 156,354 participants between 18 and 29 years old, those with higher family income were more likely to have sunburns. ${ }^{17}$

However, a multicenter study including 15 major cities in Brazil showed that the prevalence of sunlight exposure was positively associated with achieved schooling, especially in the more developed regions. 
TABLE 2: Ordinal logistic regression for sunlight exposure among men; crude and adjusted analysis. Pelotas, Brazil, 2005

\begin{tabular}{|c|c|c|c|c|c|c|c|c|}
\hline \multirow[t]{2}{*}{ Variables } & \multicolumn{2}{|l|}{$\begin{array}{l}\text { Crude sunlight } \\
\text { exposure } \\
\text { Leisure time }\end{array}$} & \multicolumn{2}{|c|}{$\begin{array}{l}\text { Adjusted sunlight } \\
\text { exposure } \\
\text { Leisure time }\end{array}$} & \multicolumn{2}{|c|}{$\begin{array}{c}\text { Crude sunlight } \\
\text { exposure } \\
\text { Work }\end{array}$} & \multicolumn{2}{|c|}{$\begin{array}{c}\text { Adjusted sunlight } \\
\text { exposure } \\
\text { Work }\end{array}$} \\
\hline & $\begin{array}{l}\text { Odds ratio } \\
95 \% \text { CI a }\end{array}$ & P value & $\begin{array}{l}\text { Odds ratio } \\
95 \% \text { CI a }\end{array}$ & P value & $\begin{array}{l}\text { Odds ratio } \\
95 \% \text { CI a }\end{array}$ & P value & $\begin{array}{l}\text { Odds ratio } \\
95 \% \text { CI a }\end{array}$ & P value \\
\hline Age (years) & & $<0.001^{*}$ & & $<0.001^{*}$ & & $<0.001^{*}$ & & $<0.001^{*}$ \\
\hline $20-29$ & 1.00 & & 1.00 & & 1.00 & & 1.00 & \\
\hline $30-39$ & $0.58(0.42-0.81)$ & & $0.66(0.47-0.94)$ & & $1.97(1.47-2.63)$ & & $1.70(1.24-2.33)$ & \\
\hline $40-49$ & $0.52(0.37-0.74)$ & & $0.57(0.39-0.81)$ & & $1.75(1.28-2.39)$ & & $1.56(1.13-2.15)$ & \\
\hline $50-59$ & $0.35(0.24-0.51)$ & & $0.36(0.25-0.54)$ & & $0.97(0.68-1.37)$ & & $0.89(0.62-1.28)$ & \\
\hline$\geq 60$ & $0.21(0.14-0.32)$ & & $0.24(0.15-0.39)$ & & $0.43(0.28-0.65)$ & & $0.33(0.21-0.52)$ & \\
\hline $\begin{array}{l}\text { Self-reported } \\
\text { skin color }\end{array}$ & & $0.04^{*}$ & & $0.3^{*}$ & & $0.08^{*}$ & & $0.5^{*}$ \\
\hline Black & 1.00 & & 1.00 & & 1.00 & & 1.00 & \\
\hline Brown (pardo) & $1.53(0.93-2.50)$ & & $1.81(1.02-3.19)$ & & $1.01(0.55-1.85)$ & & $1.18(0.63-2.18)$ & \\
\hline White & $1.47(1.05-2.06)$ & & $1.32(0.92-1.88)$ & & $0.77(0.54-1.08)$ & & $1.16(0.79-1.70)$ & \\
\hline Achieved schooling (years) & & $<0.001^{*}$ & & $<0.001^{*}$ & & $<0.001^{*}$ & & $<0.001^{*}$ \\
\hline $0-4$ & 1.00 & & 1.00 & & 1.00 & & 1.00 & \\
\hline $5-8$ & $2.41(1.68-3.45)$ & & $1.76(1.21-2.5)$ & & $1.06(0.78-1.42)$ & & $0.83(0.59-1.16)$ & \\
\hline $9-11$ & $3.00(2.05-4.39)$ & & $1.77(1.17-2.66)$ & & $0.55(0.39-0.79)$ & & $0.51(0.34-0.76)$ & \\
\hline$\geq 12$ & $4.90(3.26-7.36)$ & & $2.81(1.76-4.50)$ & & $0.28(0.17-0.46)$ & & $0.30(0.18-0.50)$ & \\
\hline $\begin{array}{l}\text { Per capita monthly } \\
\text { family income in quartiles ( } \mathrm{L}\end{array}$ & U\$) & $<0.001^{*}$ & & $0.007^{*}$ & & $<0.001^{*}$ & & $<0.001^{*}$ \\
\hline 1st (0 to 70$)$ & 1.00 & & 1.00 & & 1.00 & & 1.00 & \\
\hline 2nd (70.1 to 133 ) & $1.29(0.94-1.77)$ & & $1.23(0.88-1.71)$ & & $0.81(0.60-1.09)$ & & $0.92(0.66-1.28)$ & \\
\hline 3rd (133.1 to 267$)$ & $1.70(1.25-2.33)$ & & $1.62(1.16-2.26)$ & & $0.52(0.38-0.71)$ & & $0.76(0.56-1.04)$ & \\
\hline 4th (267.1 to 8889$)$ & $1.98(1.36-2.87)$ & & $1.67(1.09-2.57)$ & & $0.26(0.18-0.37)$ & & $0.47(0.32-0.68)$ & \\
\hline $\begin{array}{l}\text { Knowledge of any friend } \\
\text { or relative with skin cancer }\end{array}$ & & $0.4 \dagger$ & & $0.7 \dagger$ & & $0.9 \dagger$ & & $0.02 †$ \\
\hline No & 1.00 & & 1.00 & & 1.00 & & 1.00 & \\
\hline Yes & $1.13(0.83-1.55)$ & & $1.07(0.78-1.48)$ & & $1.02(0.73-1.43)$ & & $1.52(1.08-2.13)$ & \\
\hline
\end{tabular}

a $95 \% \mathrm{CI}=95 \%$ confidence interval

† Wald global association test

* Wald test for linear trend 
TABLE 3: Ordinal logistic regression for sunlight exposure among women; crude and adjusted analysis. Pelotas, Brazil, 2005

\begin{tabular}{|c|c|c|c|c|c|c|c|c|}
\hline \multirow{3}{*}{ Variables } & \multirow{2}{*}{\multicolumn{2}{|c|}{$\begin{array}{l}\text { Crude sunlight } \\
\text { exposure } \\
\text { Leisure time }\end{array}$}} & \multirow{2}{*}{\multicolumn{2}{|c|}{$\begin{array}{c}\text { Adjusted sunlight } \\
\text { exposure } \\
\text { Leisure time }\end{array}$}} & \multirow{2}{*}{\multicolumn{2}{|c|}{$\begin{array}{c}\text { Crude sunlight } \\
\text { exposure } \\
\text { Work }\end{array}$}} & \multirow{2}{*}{\multicolumn{2}{|c|}{$\begin{array}{c}\text { Adjusted sunlight } \\
\text { exposure } \\
\text { Work }\end{array}$}} \\
\hline & & & & & & & & \\
\hline & $\begin{array}{l}\text { Odds ratio } \\
95 \% \text { CI a }\end{array}$ & P value & $\begin{array}{l}\text { Odds ratio } \\
95 \% \text { CI a }\end{array}$ & P value & $\begin{array}{l}\text { Odds ratio } \\
95 \% \text { CI a }\end{array}$ & P value & $\begin{array}{l}\text { Odds ratio } \\
95 \% \text { CI a }\end{array}$ & P value \\
\hline Age (years) & & $<0.001^{*}$ & & $<0.001^{*}$ & & $0.006^{*}$ & & $0.02^{*}$ \\
\hline $20-29$ & 1.00 & & 1.00 & & 1.00 & & 1.00 & \\
\hline $30-39$ & $0.50(0.37-0.67)$ & & $0.57(0.41-0.81)$ & & $0.93(0.54-1.59)$ & & $0.89(0.52-1.53)$ & \\
\hline $40-49$ & $0.37(0.27-0.51)$ & & $0.46(0.33-0.63)$ & & $1.43(0.88-2.31)$ & & $1.35(0.83-2.17)$ & \\
\hline $50-59$ & $0.24(0.16-0.35)$ & & $0.25(0.17-0.38)$ & & $0.98(0.57-1.66)$ & & $0.98(0.58-1.65)$ & \\
\hline$\geq 60$ & $0.14(0.10-0.21)$ & & $0.21(0.13-0.32)$ & & $0.35(0.19-0.62)$ & & $0.33(0.18-0.61)$ & \\
\hline Self-reported skin color & & $0.08^{*}$ & & $0.7^{*}$ & & $0.2^{*}$ & & $0.7^{*}$ \\
\hline Black & 1.00 & & 1.00 & & 1.00 & & 1.00 & \\
\hline Brown (pardo) & $1.12(0.72-1.74)$ & & $1.08(0.67-1.74)$ & & $0.77(0.42-1.44)$ & & $0.84(0.45-1.59)$ & \\
\hline White & $1.37(0.94-2.00)$ & & $0.95(0.63-1.44)$ & & $0.70(0.44-1.12)$ & & $0.90(0.55-1.46)$ & \\
\hline Achieved schooling (years) & & $<0.001^{*}$ & & $<0.001^{*}$ & & $0.06^{*}$ & & $0.1^{*}$ \\
\hline $0-4$ & 1.00 & & 1.00 & & 1.00 & & 1.00 & \\
\hline $5-8$ & $2.06(1.40-3.02)$ & & $1.42(0.97-2.08)$ & & $0.97(0.60-1.56)$ & & $0.76(0.47-1.25)$ & \\
\hline $9-11$ & $5.35(3.59-7.96)$ & & $2.74(1.80-4.16)$ & & $0.76(0.46-1.26)$ & & $0.67(0.40-1.13)$ & \\
\hline$\geq 12$ & $10.86(7.30-16.15$ & & $4.93(3.10-7.87)$ & & $0.61(0.34-1.08)$ & & $0.66(0.36-1.23)$ & \\
\hline $\begin{array}{l}\text { Per capita monthly } \\
\text { family income in quartiles ( }\end{array}$ & (U\$) & $<0.001^{*}$ & & $0.002^{*}$ & & $<0.001^{*}$ & & $0.006^{*}$ \\
\hline 1st (0 to 70$)$ & 1.00 & & 1.00 & & 1.00 & & 1.00 & \\
\hline 2nd (70.1 to 133$)$ & $1.23(0.87-1.75)$ & & $1.10(0.75-1.59)$ & & $0.90(0.60-1.35)$ & & $0.99(0.66-1.46)$ & \\
\hline 3rd (133.1 to 267$)$ & $1.65(1.14-2.39)$ & & $1.40(0.91-2.16)$ & & $0.47(0.30-0.72)$ & & $0.58(0.37-0.91)$ & \\
\hline 4th (267.1 to 8889$)$ & $3.15(2.21-4.48)$ & & $2.02(1.27-3.21)$ & & $0.40(0.24-0.67)$ & & $0.52(0.30-0.90)$ & \\
\hline $\begin{array}{l}\text { Knowledge of any friend } \\
\text { or relative with skin cance }\end{array}$ & & $0.02^{\dagger}$ & & $0.3^{\dagger}$ & & $0.4^{\dagger}$ & & $0.7^{\dagger}$ \\
\hline No & 1.00 & & 1.00 & & 1.00 & & 1.00 & \\
\hline Yes & $1.39(1.07-1.81)$ & & $1.15(0.87-1.51)$ & & $0.82(0.54-1.25)$ & & $0.93(0.61-1.42)$ & \\
\hline
\end{tabular}


Sunlight exposure among individuals with higher schooling was more frequent during leisure-time activities. On the other hand, those with lower schooling were more likely to be exposed to sunlight at work, but also during leisure-time activities. ${ }^{18}$

With reference to age, independently of sex, younger individuals were more likely to be exposed to sunlight at the beach than at work. This finding corroborates those of previous national and international studies, which found that sunlight exposure was more frequent among younger individuals. ${ }^{18,19}$ As described in other studies, younger individuals tend to adopt risky behaviors, including exposure to sunlight. ${ }^{16,20,21}$ Furthermore, younger individuals are more likely to be influenced by the current aesthetic ideal and, therefore, may have a stronger desire for tanned skin.

Self-reported skin color was not associated with sunlight exposure in the adjusted analysis. Contrary to our expectations, browns and whites were similarly exposed to sunlight when compared with blacks.

Knowledge of any friend or relative who had skin cancer was positively associated with sunlight exposure only among men at work. This was an unexpected find- ing and may be the result of a spurious association, since it is not supported by the literature reviewed.

Undoubtedly, the most effective way to decrease the incidence of cutaneous neoplasms and other sunsensitive diseases is through reducing the frequency of sunlight exposure. The amount of available information on the dangers of sun exposure is increasing in Brazil; however, the incidence of skin cancer is also increasing in the country. ${ }^{15}$ As shown in this study, sociodemographic determinants were associated with sunlight exposure at leisure time and at work.

\section{CONCLUSION}

Exposure to sunlight at leisure time seems to be associated with the valorization of tanned skin. Sunlight exposure at work was higher among lower income individuals. These individuals are more likely to fill low-paying unskilled job positions and, as a result, they may have to live in disadvantaged conditions that may endanger their health and impose greater barriers to ascending to higher social levels. These findings should be of deep concern to health authorities and health professionals.

\section{REFERENCES}

1. Frost CA, Green AC, Williams GM. The prevalence and determinants of solar keratoses at a subtropical latitude (Queensland, Australia). Br J Dermatol. 1998;139:1033-9.

2. Lowe NJ. An overview of ultraviolet radiation, sunscreens, and photo-induced dermatoses.Dermatol Clin. 2006;24:9-17.

3. Souza SR, Fischer FM, Souza JM. Suntanning and risk of cutaneous melanoma: a literature review. Rev Saude Publica. 2004;38:588-98.

4. Breitbart EW, Greinert R, Volkmer B. Effectiveness of information campaigns. Prog Biophys Mol Biol. 2006;92:167-72.

5. Nole G, Johnson AW. An analysis of cumulative lifetime solar ultraviolet radiation exposure and the benefits of daily sun protection. Dermatol Ther. 2004;17:S57-62.

6. Albert MR, Ostheimer KG. The evolution of current medical and popular attitudes toward ultraviolet light exposure: part 2. J Am Acad Dermatol. 2003;48:909-18.

7. Albert MR, Ostheimer KG. The evolution of current medical and popular attitudes toward ultraviolet light exposure: part 3. J Am Acad Dermatol. 2003:49:1096-106.

8. Gontijo S. Oitenta anos de moda no Brasil. Rio de Janeiro: Nova Fronteira; 1987. $130 \mathrm{p}$.

9. Souza SRP. Tendência temporal da mortalidade por melanoma cutâneo no estado de São Paulo, 1979-1998 [tese]. São Paulo (SP): Universidade de São Paulo; 2001.

10. Duquia RP, Baptista Menezes AM, Reichert FF, de Almeida HL Jr. Prevalence and associated factors with sunscreen use in southern Brazil: A population-based study. J Am Acad Dermatol. 2007;57:73-80

11. Newton R, Ferlay J, Reeves G, Beral V, Parkin DM. Effect of ambient solar ultraviolet radiation on incidence of squamous-cell carcinoma of the eye. Lancet. 1996;347:1450-1.

12. Gallagher RP, Spinelli JJ, Lee TK. Tanning beds, sunlamps, and risk of cutaneous malignant melanoma. Cancer Epidemiol Biomarkers Prev. 2005;14:562-6.

13. Delcourt C, Carriere I, Ponton-Sanchez A, Lacroux A, Covacho MJ, Papoz L. Light exposure and the risk of cortical, nuclear, and posterior subcapsular cataracts: the Pathologies OculairesLiees a l'Age (POLA) study. Arch Ophthalmol. 2000;118:385-92.

14. Luthra R, Nemesure BB, Wu SY, Xie SH, Leske MC; Barbados Eye Studies Group. Frequency and risk factors for pterygium in the Barbados Eye Study.Arch Ophthalmol. 2001:119:1827-32.

15. Brasil. Ministério da Saúde. Secretaria de Atenção à Saúde. Instituto Nacional de Câncer. Coordenação de Prevenção e Vigilância. Estimativa 2006: incidência do câncer no Brasil. 2006.Rio de Janeiro: INCA; 2005. 94 p.
16. Robinson JK, Rigel DS, Amonette RA. Trends in sun exposure knowledge, attitudes, and behaviors: 1986 to 1996. J Am Acad Dermatol. 1997;37:179-86.

17. Saraiya M, Hall HI, Uhler RJ. Sunburn prevalence among adults in the United States, 1999. Am J Prev Med. 2002;23:91-7.

18. Szklo AS, Almeida LM, Figueiredo V, LozanaJde A, Azevedo e Silva Mendonca G, Moura $\mathrm{L}$, et al. Behaviors related to sunlight exposure versus protection in a random population sample from 15 Brazilian State capitals and the Federal District, 2002-2003. Cad Saude Publica.2007;23:823-34.

19. Koh HK, Bak SM, Geller AC, Mangione TW, Hingson RW, Levenson SM,et al. Sunbathing habits and sunscreen use among white adults: results of a national survey. Am J Public Health.1997;87:1214-7.

20. Melia J, Bulman A. Sunburn and tanning in a British population. J Public Health Med. 1995; $17: 223-9$

21. Rhainds M, De Guire L, Claveau J. A population-based survey on the use of artificial tanning devices in the Province of Quebec, Canada. J Am Acad Dermatol. 1999;40:572-6.

\author{
MAILING ADDRESS: \\ Rodrigo Pereira Duquia \\ Álvaro Alvim, 169, 1104 \\ CEP: 90420-020 - Porto Alegre - RS \\ Brazil \\ E-mail: rodrigoduquia@gmail.com
}

How to cite this article: Duquia RP, Menezes AMB, Almeida HL Jr, Reichert FF, Santos IS, Haack RL, Horta BL. Prevalence of sun exposure and its associated factors in southern Brazil: a population-based study. An Bras Dermatol. 2013;88(4):554-61. 